\title{
Influence of lean-green practices on organizational sustainable performance
}

\author{
Manori Pathmalatha Kovilage \\ Faculty of Management Studies, Department of Tourism Management, \\ Sabaragamuwa University of Sri Lanka, Belihuloya, Sri Lanka
}

Influence of lean-green practices

Received 22 November 2019 Revised 4 March 2020 Accepted 29 May 2020

\begin{abstract}
Purpose - The key objectives of this study were to investigate the interactions among the lean, green management practices and organizational sustainable performance measures and explore the possibility of simultaneous implementation of these concepts for improving the organizational sustainable performance. Design/methodology/approach - Using the interpretive structural modeling (ISM) technique, the interactions among the lean, green practices and organizational sustainable performance measures were established. A focus group which consisted of purposively selected 15 experts was utilized in the primary data collection.

Findings - In Sri Lankan context, water and material consumption reduction, energy efficiency, water pollution and greenhouse gas reduction were identified as the dominant green practices, while pull production, lot size reduction, continuous improvement, preventive maintenance, employee involvement and cycle time reduction were the dominant lean practices. Inventory level, profitability, quality, cost, employee satisfaction, customer satisfaction, lead time, resources consumption (material, water, energy) and waste generation were determined as the dominant sustainable performance measures. The resulting ISM-based structural model which consisted of eight levels concluded that firstly lean practices influence the green practices and afterward green practices affect the sustainable performance measures.

Research limitations/implications - The aim of this study was to develop a hypothetical structural model to explain the interactions among the lean, green management practices and organizational sustainable performance measures. But this hypothetical model was not empirically tested in the current study. So further study is required to empirically test the proposed model.

Practical implications - Currently organizations who practice for sustainable performance engages, lean and green practices separately without understanding on which practices are stared when and how. So, through the findings of this study, organization who desire to improve the sustainable performance are recommended to begin the journey with lean practices and subsequently move in to green and handle both lean and green initiatives through one functional unit.

Originality/value - The existing literature does not possess a model for explaining the lean-green synergy and organizational sustainable performance and this study successfully fills this gap. Also the study proposes for the practitioners, when and how the lean and green practices should be initiated and implemented for rising the sustainable performance of an organization.
\end{abstract}

Keywords Lean management, Green management, Sustainable performance measures, Interpretive structural modeling, Sustainability, Management

Paper type Research paper

\section{Introduction}

At the end of 20th century, getting a start from the report "Our Common Future" (Brundtland, 1987) the sustainability thinking and sustainable development was started to integrate in to

\section{JEL Classification - O13, P18, Q56}

(C) Manori Pathmalatha Kovilage. Published in Journal of Asian Business and Economic Studies. Published by Emerald Publishing Limited. This article is published under the Creative Commons Attribution (CC BY 4.0) licence. Anyone may reproduce, distribute, translate and create derivative works of this article (for both commercial and non-commercial purposes), subject to full attribution to the original publication and authors. The full terms of this licence may be seen at http://creativecommons. org/licences/by/4.0/legalcode

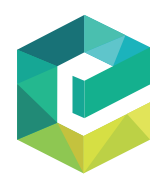

Journal of Asian Business and Economic Studies Vol. 28 No. 2,2021 pp. $121-142$ Emerald Publishing Limited 2515-964X DOI 10.1108/JABES-11-2019-0115 
JABES

28,2

the organizational strategy (Enquist et al., 2007). The sustainable development refers to the "development that meets the needs of the present without compromising the ability of future generations to meet their own needs" (Brundtland, 1987) and organizational sustainable performance is the key path of the sustainable development in a country, region or whole the world. As a consequence, sustainability measures were initiated to incorporate in the organizational performance evaluation models. With this startup organizations which perceive the organizational performance in a financial facet accepted the sustainable performance which combine the economic, social and environmental (triple) bottom lines (Elkington, 1998) as their performance target (Sebhatu, 2008).

In achieving the corporate sustainable performance, organizations are applying different kind of efforts today. Lean and green are several cutting-edge paradigms which are often applied in ensuring the organizational sustainable performance by the corporate sector (Azevedo et al., 2016). The concept, lean signifies a system which utilize less inputs to create the same output as those created by a traditional mass production system while contributing increased varieties for the end customer and it aims to reduce or eliminate non-value-added activities throughout a product value stream (Womack and Jones, 1994). Meanwhile the concept green management limits or reduces the potential negative impacts of the production and consumption of goods and services on the natural environment, while improving the company's environmental footprint (Galeazzo et al., 2014; Verrier et al., 2014). As emphasized by the scholars, there are some synergies among these concepts (Wu et al., 2015). But most of the organizations have forgotten about these synergies and these concepts are implemented separately by different units and departments. Then the consequence is overlapping efforts and extra expenses (Weise et al., 2015) which increase the distance to the destination sustainable performance.

As a solution for these inefficiencies, scholars have started to research on the possibility for synergetic or simultaneous implementation of these philosophies and its impact on the organizational performance. In this research context, the existing research efforts can be grouped around the following key research areas such as lean and green synergies (Hallam and Contreras, 2016; Bergmiller and McCright, 2009; Cabral et al., 2012; Dües et al., 2013; Galeazzo et al., 2014), lean-green synergy and organizational performance (Farias et al., 2019; Thanki et al., 2016), lean-green synergy and sustainable performance (Khalili et al., 2016), lean and sustainable manufacturing on performance (Hartini and Ciptomulyono, 2015), lean manufacturing and sustainable performance (Henao et al., 2019), lean-green-social management and sustainable performance (Wu et al., 2015), integration of lean, green and best practice business principles (Weise et al., 2015), synergies among lean-green-agile resilient practices(Azevedo et al., 2016) and lean management, supply chain management and sustainability (Jurado et al., 2014).

In the case of lean-green synergy and sustainable performance, most of the previous studies have focused the supply chain perspective and individual organizational perspective has been neglected (Garza-Reyes, 2015; Govindan et al., 2015). Then, Khalili et al. (2016), who researched on lean-green synergy and organizational sustainable performance has proposed a model to explain the interaction among lean, green and organizational sustainable performance measures in the manufacturing-oriented organizations. In this model lean approach has been explained through 4 Ps: problemsolving, process, philosophy and people. Then green approach has been explained through ISO 14001 Environmental Management System Standards. This model has been developed theoretically and not been empirically tested. Further, this paper has been addressed the interaction of the lean-green management and organizational performance in the manufacturing sector only. So, it denotes that existing studies are not enough to comprehensively understand the interactions of lean and green management practices and organizational sustainable performance. 
So also, in the Sri Lankan context, no research was found which addressed this research area. But most of industrial organizations in Sri Lanka are implementing both concepts separately and they are ignorant on the possibility of synergetic implementation of lean and green concepts. Further they are uninformed on the interactions among lean-green and organizational sustainable performance measures. There for, the main aim of this study was to investigate the interactions of the lean management, green management and sustainable performance measures and explore the possibility of simultaneous implementation of these concepts for improving the organizational sustainable performance in Sri Lanka. In achieving these research objectives, the study does not limit for a particular industry or sector and it is a holistic study which covers all the industrial categories. Further, the research aimed to explain the interactions of the lean-green practices and the organizational sustainable performance measures through a hypothetical structural model because existing literature does not possess such a model for explain the lean-green synergy and organizational sustainable performance. So, it establishes the empirical gap of the study. Here the researcher expects to develop the structural model base on the interpretive structural modeling approach, proposed by the Warfield (1974).

\section{Literature review}

\subsection{Existing studies on "strategy integration for sustainable performance"}

As a strategy for achieving the sustainable performance, nowadays organizations are focusing the strategy integration. Under this integration, lean-green integration, lean, green and social management integration, lean, green, agile and resilience practices integration are prominent among the current scholars. Table 1 demonstrate the research areas which were done under the strategy integration.

In the context of strategy integration for sustainable performance, the researcher identified the existing research gap in the research area of "lean-green synergy and sustainable performance" or integration of lean and green strategies (paradigms) to achieve the sustainable performance. Here, the identified research gap is, unavailability of a comprehensive model to explain the interaction among lean-green paradigms (strategies/ practices) and the organizational sustainable performance.

\subsection{Organizational sustainable performance}

The term organizational performance is defined as "a measure of organizational efforts to determine, implement and adapt organizational strategies successfully" (David, 2011). Historically, the concept of organizational performance is too often approximated to the financial performance. In consequence, the organizational performance was often measured with the financial preferable indicators such as return on investments, sales, profit per share (Morin, 1995).

Then, gradually organizations' focus tuned toward the sustainable business performance beyond the financial performance (Lee and Saen, 2011). The sustainable performance of a company is judged according to its economic, environmental and social performance (Lee and Saen, 2011). Global Reporting Initiative (GRI), Composite Sustainable Development Index and Sustainability BSC (SBSC) are several existing sustainable performance measures.

The GRI offers a voluntary reporting frame-work that comprises goals and operationalized indicators with regard to environmental, economic and social performance (Global Reporting Initiative, 2017). Here the environmental dimension of sustainability concerns the organization's impact on living and nonliving natural systems, including land, air, water and ecosystems. The social dimension of sustainability concerns the impacts, the organization has on the social systems within which it operates. The social category includes 


\section{JABES 28,2}

The research area

Lean-green synergy (synergies between lean and green management): These authors have discussed the synergies and differences between the lean and green paradigms

Lean-green and organizational performance: These authors have discussed the impact of lean and green strategies/practices on the organizational financial performance. They have focused the individual impact of lean and green practices on the organizational performance, but not tested the possibility of implementation of lean and green simultaneously for improving the organizational performance

Lean-green synergy and sustainable performance: The author has focused on the relationships of lean, green manufacturing and sustainable performance. In this model lean approach has been explained through: problem-solving, process, philosophy and people. Then green approach has been explained through ISO 14001 Environmental Management System Standards. This model has been developed theoretically concerning only the manufacturing sector and not been empirically tested

Lean - green- social management and sustainable performance: The impact of integrated practices of lean, green, and social management systems on firm sustainability performance has been observed, getting evidence from Chinese Fashion Auto-Parts Suppliers

The integration of lean, green and best practice business principles: The integration possibility of lean, green and best practice business

Table 1.

Research areas and authors in strategy integration principles has been studied in this paper

Lean-green-agile-resilient practices - LARG index: This is an attempt to develop a benchmarking tool for improving the leanness, agility, resilience and greenness of the automotive supply chain
Author

Hallam and Contreras (2016);

Bergmiller and

McCright (2009); Cabral et al. (2012);

Dües et al. (2013); Galeazzo et al. (2014)

Farias et al. (2019); Thanki et al. (2016)

Khalili et al. (2016)

Wu et al. (2015)

Weise et al. (2015)

Azevedo et al. (2016)

the subcategories: labor practices and decent work, human rights, society and product responsibility (Global Reporting Initiative, 2017). The economic dimension of sustainability concerns the organization's impacts on the economic conditions of its stakeholders, and on economic systems at local, national and global levels (Global Reporting Initiative, 2017).

"GRI is also the case for the Composite Sustainable Development Index (ICSD) which is composed of the economic sub-index, the environmental sub-index and the social sub-index" (Krajnc and Glavic, 2005). These subindices are in turn composed of correspondingly "normalized economic, environmental and social indicators extracted from other frameworks including GRI" (Krajnc and Glavic, 2005). The Balanced Score Card (BSC) contains four aspects as financial, customer, internal processes, learning and growth for which performance indicators ensure alignment between strategies and operations (Kaplan and Norton, 1996). The BSC is an open system which means that all stakeholder interests can be included if they are important for the success of a strategy. Therefore, integrating the environmental goals, BSC can be expanded as the Sustainability BSC (SBSC) (Moller and Schaltegger, 2005). To derive the SBSC two ways can be followed. The first way is integrating the environmental goals into the existing four performance perspectives of the BSC. The second way is adding a separate perspective for the environmental concern (Krajnc and Glavic, 2005).

\subsection{Lean paradigm}

Lean, originally developed on the shop floors of Japanese car manufacturers, is still sometimes understood as a synonym for Toyota Production System (TPS). Eiji Toyoda and 
Taiichi Ohno at the Toyota Motor Company in Japan pioneered the concept of the "Toyota Production System" or which is named as the "Lean Production or Lean Manufacturing" in the American manufacturing system (Bhasin, 2015). Gradually the lean concept which was originally spread in the manufacturing industries, was begun to spread in the service industries too.

The basic idea behind the "lean" is eliminating waste which is defined as anything that does not add value to the end product from the customer's perspective. For an organization the waste may be material, inventory, overproduction, unwanted movements of labor, complexity, energy, space, defects, transportation, setup time, etc. (Womack and Jones, 1994). Lean philosophy has introduced some tools to eliminate these wastes and ensure the continues improvement. Those tools includes: 5 S, Value Stream mapping, Kanban, Standardized work, PDCA Problem-solving, Total Quality Management, Total Productive Maintenance, Single Minute Exchange of Die(SMED), Five Why, Gemba (The Real Place), Jidoka (Autonomation), Visual Factory, Just in Time and Kizen (Bhasin, 2015).

The lean concept has built on five key principles as value, value stream, flow, pull and perfection (Womack and Jones, 1996). Here the first principle value refers to the customer perceived value and lean thinking start with a conscious attempt to precisely define value through a dialog with a specific customer, since only they can define what is valuable to them (Womack and Jones, 1996). The second principle value stream is a series of actions produced by an organization to create value for the customer. Analyzing the value stream aims to identify value-adding activities that are necessary for producing and delivering a product or service to the customer and nonvalue adding activities that prevents the flow of value through the process (Womack and Jones, 1996). Third lean principle flow refers to an ideal value stream in which the product or services never stops and move from start to finish continuously (Womack and Jones, 1996). The objective is to move material and work in process (WIP) from one value-adding step directly to the next value-adding step, and then to the customer without waiting, downtime or waste within or between the steps (Womack and Jones, 1996). The fourth principle, pull means that nothing should be produced upstream until the downstream customer asks for it. In an ideal "one-by-one flow, the product flows continually to the customer only after the signal from the requesting customer" (Womack and Jones, 1996). The objective is thus to produce only what the customer wants just when the customer wants it (Womack and Jones, 1996). The fifth principle perfection can be realized through proper implementation of the first four principles. For achieving the perfection, there is no end to the continuous process improvements (Womack and Jones, 1996).

\subsection{Green management}

The concept green management which was started to discuss in last few decades is a key strategy for the sustainable development (Banerjee, 2002). In the broader aspect, green management involves the integration of the environment in organizational decision-making. It refers to the "practices that produce environmentally-friendly products and minimize the impact on the environment through green production, green research and development, and green marketing" (Peng and Lin, 2008). A business organization that adopt with the green management principles, policies and practices refers as a green business. A green business can be derived from two perspectives related to the output in the form of green products (goods and services) as well as the production process (Loknath and Azeem, 2017). Reduction of regulatory risk, decreasing the customers' exposure to unhealthy substances, increasing the reuse and recycling of materials used in the production process, improving the energy efficiency, resource productivity, waste reduction, pollution prevention, collecting and disseminating more information about the firm's environmental impacts and performance than the law requires, providing more opportunities for stakeholder input into corporate 
JABES

28,2

environmental decision-making than the law requires and financing and investing in green products and business models are the green practices adapts by green businesses to accomplish the green management (Loknath and Azeem, 2017).

\subsection{Green, lean practices and sustainable performance measures}

Table 2 summarizes the lean, green management practices and organizational sustainable performance measures which were identified through surveying existing literature.

\section{Methodology}

The purpose of this study was to investigate the interactions of the lean, green management practices and organizational sustainable performance measures and explore the possibility of simultaneous implementation of these concepts for improving the organizational sustainable performance and finally to develop a structural model that explain these interactions. In achieving the research purpose, the study followed the constructivist research philosophy. "Constructivism or social constructivism (often combined with interpretivism) is such a perspective, and it is typically seen as an approach to qualitative research" (Creswell, 2014, p. 37). Thus, the research followed the qualitative research approach with qualitative data collection methods: unstructured interviews and focus group interviews. Here, in developing the structural model, the "Interpretive Structural Modeling (ISM) Technique" was followed.

ISM technique was introduced by Warfield in 1973 for studying the multifaceted socioeconomic systems. "ISM is found to be a well-proven and widely accepted system modelling approach for analyzing the interrelationships between the variables influencing a system" (Warfield, 1974). Further the ISM approach is more applicable when the study requires a "multilevel research design involvement" and the outcome of the research cannot be predicted based on available research studies (Klein and Kozlowski, 2000 cited in Govindan et al., 2015). The ISM follows a process which comprises eight stages in developing the structural model for a particular research problem. Correspondingly, those stages comprise: identification of elements, establishing a contextual relationship between elements, developing a structural self-interaction matrix (SSIM) of elements, developing a reachability matrix from the SSIM, partitioning of a reachability matrix into different levels, draw a directed graph (DIGRAPH) to remove transitive links, conversion of the resultant digraph into an ISM and review of the ISM model to check for conceptual inconsistency (Warfield, 1974). Figure 1 demonstrate the flow of the study which followed the ISM process explained by the Warfield (1974).

Aligning with the ISM methodology, at start, lean, green management practices and organizational sustainable performance measures which were widely applied in the Sri Lankan business organizations were identified through surveying existing literature and engaging unstructured interviews with 10 industry experts and five academics who possess a sound knowledge in this particular research area. Here, these experts were selected purposively, concerning their expertise on lean and green paradigms, because the qualitative approach propose the nonprobabilistic sampling techniques like purposive sampling (Creswell, 2014). Then, the focus group interview technique was utilized to determine the key lean, green management practices and organizational sustainable performance measures and relationships among the key lean, green management practices and organizational sustainable performance measures. Because the ISM approach often recommends the focus group interviews, nominal group technique and brainstorming sessions for identifying the interactions among the research variables (Warfield, 1974). Here, the focus group consisted of 15 experts (they are separate from previous interviewees) who also represented the industry and academia and were expertise on green and lean management approaches. These experts 


\begin{tabular}{|c|c|c|c|}
\hline Green practices & Description & Source & \\
\hline $\begin{array}{l}\text { Water consumption } \\
\text { reduction }\end{array}$ & $\begin{array}{l}\text { "Efforts for reduction of water consumption in the business } \\
\text { operations" }\end{array}$ & $\begin{array}{l}\text { Farias et al. } \\
(2019)\end{array}$ & practices \\
\hline $\begin{array}{l}\text { Water pollution } \\
\text { reduction }\end{array}$ & $\begin{array}{l}\text { "Reduction of contamination of water bodies as a result of } \\
\text { business operations" }\end{array}$ & $\begin{array}{l}\text { Farias et al. } \\
(2019)\end{array}$ & \\
\hline Energy efficiency & $\begin{array}{l}\text { "Usage of less energy to perform the same operations in the } \\
\text { business organization, through eliminating waste" }\end{array}$ & $\begin{array}{l}\text { Farias et al. } \\
(2019)\end{array}$ & 127 \\
\hline Material efficiency & $\begin{array}{l}\text { "Usage of less material resources to perform the same operations } \\
\text { in the business organization, through eliminating waste" }\end{array}$ & $\begin{array}{l}\text { Farias et al. } \\
(2019)\end{array}$ & \\
\hline GHG emission reduction & $\begin{array}{l}\text { "Reduction of quantity of greenhouse gasses released to the } \\
\text { atmosphere through the business operations" }\end{array}$ & $\begin{array}{l}\text { Farias et al. } \\
(2019)\end{array}$ & \\
\hline Lean practices & Description & Source & \\
\hline Pull production/flow & $\begin{array}{l}\text { "An approach to produce only what the customer wants just } \\
\text { when the customer wants it, thereby the production systems are } \\
\text { flexible enough to accommodate shifting demand immediately" }\end{array}$ & $\begin{array}{l}\text { Farias et al. } \\
(2019)\end{array}$ & \\
\hline Lot size reduction & $\begin{array}{l}\text { "Lot size refers to the quantity of an item ordered for delivery on } \\
\text { a specific date or manufactured in a single production run. A } \\
\text { small, lot size causes reduction in inventory level, variability in } \\
\text { the system and ensures smooth production" }\end{array}$ & $\begin{array}{l}\text { Wu et al. } \\
(2015)\end{array}$ & \\
\hline $\begin{array}{l}\text { Continuous } \\
\text { improvement/Kaizen }\end{array}$ & $\begin{array}{l}\text { "Activities that continuously improve all functions and involve } \\
\text { all employees from the CEO to the assembly line workers" }\end{array}$ & $\begin{array}{l}\text { Farias et al. } \\
\text { (2019) }\end{array}$ & \\
\hline Preventive maintenance & $\begin{array}{l}\text { "Preventive maintenance (or preventative maintenance) is } \\
\text { maintenance that is regularly performed on a piece of equipment } \\
\text { to lessen the likelihood of it failing. It is performed while the } \\
\text { equipment is still working so that it does not break down } \\
\text { unexpectedly" }\end{array}$ & $\begin{array}{l}\text { Kovilage } \\
(2018)\end{array}$ & \\
\hline Employee involvement & $\begin{array}{l}\text { "A situation where employees participate directly to help an } \\
\text { organization to fulfill its mission and meet its objectives by } \\
\text { applying their ideas, expertise, and efforts towards problem } \\
\text { solving and decision making" }\end{array}$ & $\begin{array}{l}\text { Kovilage } \\
(2018)\end{array}$ & \\
\hline Cycle time reduction & $\begin{array}{l}\text { "Cycle time, also called throughput time, is the amount of time } \\
\text { required to produce a product or service. Cycle time reduction is } \\
\text { achieved by reducing the time spent on non-value-added } \\
\text { activities and simplification and streamlining of the process" }\end{array}$ & $\begin{array}{l}\text { Wu et al. } \\
(2015)\end{array}$ & \\
\hline $\begin{array}{l}\text { Sustainable performance } \\
\text { measures }\end{array}$ & Description & Source & \\
\hline Inventory level & $\begin{array}{l}\text { "Inventory refers to the items that are kept in stock to process or } \\
\text { resell. Keeping a high level of inventory adds a cost to the } \\
\text { business as inventory handling, holding, obsoleteness, etc." }\end{array}$ & $\begin{array}{l}\text { Farias et al. } \\
(2019)\end{array}$ & \\
\hline Profitability & $\begin{array}{l}\text { "The degree to which a business or activity yields profit or } \\
\text { financial gain" }\end{array}$ & $\begin{array}{l}\text { Farias et al. } \\
(2019)\end{array}$ & \\
\hline Waste generation & $\begin{array}{l}\text { "Amount of total waste generates through all the processes in a } \\
\text { business" }\end{array}$ & $\begin{array}{l}\text { Farias et al. } \\
(2019)\end{array}$ & \\
\hline Quality & "It refers to the fitness for use or conformance to the standard" & $\begin{array}{l}\text { Farias et al. } \\
(2019)\end{array}$ & \\
\hline Cost & $\begin{array}{l}\text { "It refers the value of money that has been used up to produce } \\
\text { something or deliver a service, and hence is not available for use } \\
\text { anymore" }\end{array}$ & $\begin{array}{l}\text { Farias et al. } \\
(2019)\end{array}$ & \\
\hline Employee satisfaction & $\begin{array}{l}\text { "Employee satisfaction is the term used to describe whether } \\
\text { employees are happy and fulfilling their desires and needs at } \\
\text { work" }\end{array}$ & $\begin{array}{l}\text { Wu et al. } \\
(2015)\end{array}$ & \\
\hline Customer satisfaction & $\begin{array}{l}\text { "It refers how products and services supplied by a company meet } \\
\text { or surpass customer expectation" }\end{array}$ & $\begin{array}{l}\text { Wu et al. } \\
\text { (2015) }\end{array}$ & \\
\hline Lead time & $\begin{array}{l}\text { "The time elapse between order receiving from the customer to } \\
\text { delivering the order to the customer" }\end{array}$ & $\begin{array}{l}\text { Kovilage } \\
(2018)\end{array}$ & $\begin{array}{r}\text { Table } 2 . \\
\text { n, lean practices }\end{array}$ \\
\hline Resources consumption & $\begin{array}{l}\text { "Amount of material, energy and water usage for the operations } \\
\text { in a business organization" }\end{array}$ & $\begin{array}{l}\text { Kovilage } \\
(2018)\end{array}$ & $\begin{array}{r}\text { and sustainable } \\
\text { performance measures }\end{array}$ \\
\hline
\end{tabular}


JABES

28,2

\section{8}

Figure 1.

Flow of the study based on the ISM process explained by Warfield (1974)

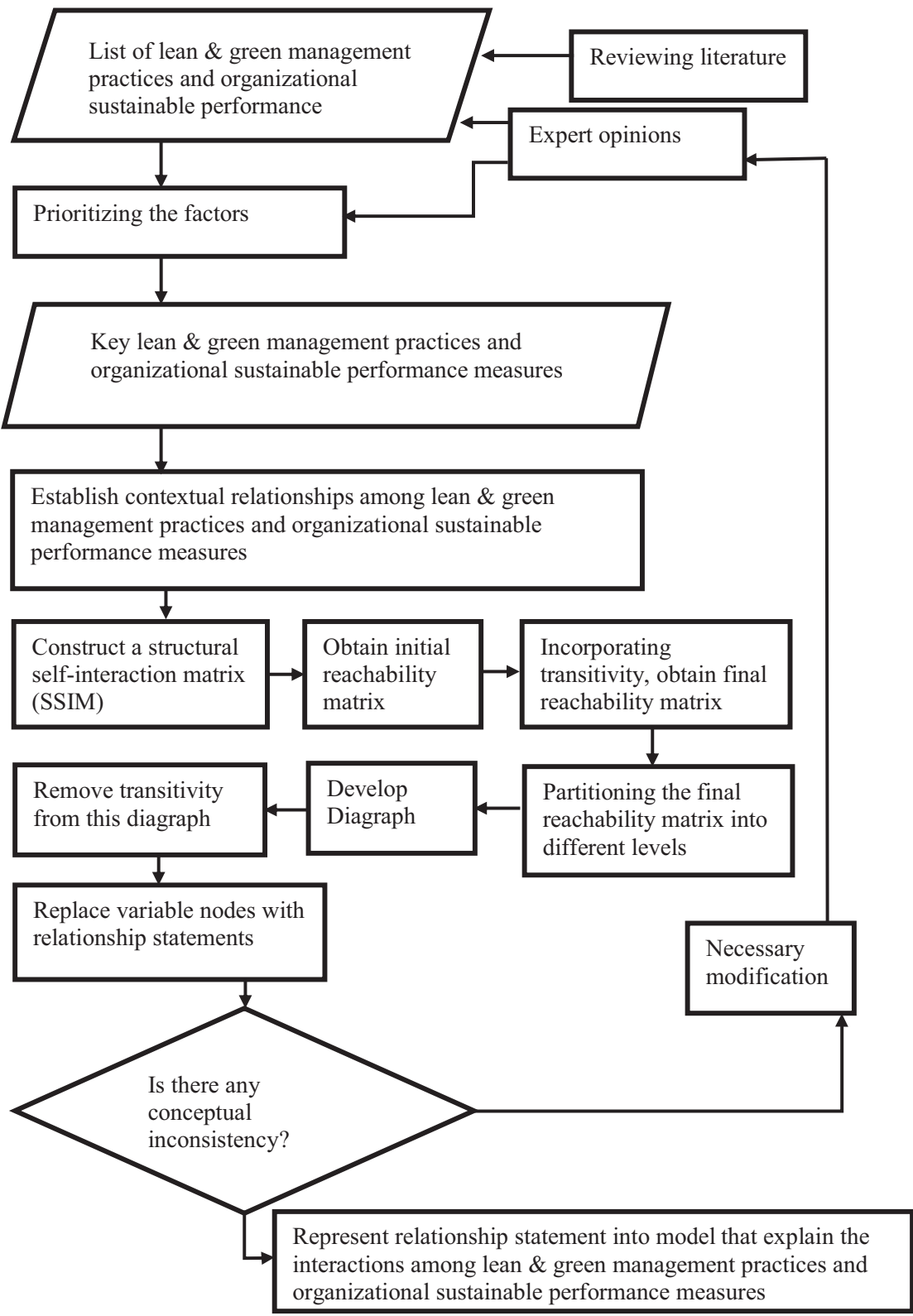

also were selected purposively, concerning their expertise. As Figure 1 (flow of the study), demonstrates, a Structural Self-Interaction Matrix (SSIM) (see Matrix 1 in the results) was used to document the experts' opinions on the interactions among the key lean, green management practices and organizational sustainable performance measures. Afterward, based on the relationships emphasized in the SSIM, the Initial Reachability Matrix (IRM) was developed. 
Then concerning the transitivity of each relationship (e.g. Variable " $A$ " affects to Variable " $B$ " and variable " $B$ " affects to Variable " $C$ ", so variable " $A$ " affects to Variable " $C$ " also), the Final Reachability Matrix (FRM) was developed. Then, through the FRM, the driving power, dependence power and levels (levels in the structural model) of each lean, green management practices and organizational sustainable performance measures were determined. Here an algorithm-based process was followed (see Tables 3-10). Afterward, the final reachability matrix was decomposed to create the structural model, that is, a directed graph. Subsequently, the transitive links were removed from the directed graph and ISM-based model of the lean, green management practices and organizational sustainable performance measures were developed based on the relationships, emphasized in the SSIM, and levels, determined through the algorithm-based process. Further each lean, green management practices and organizational sustainable performance measures were classified as independent, dependent, autonomous and linkage variables with the help of MICMAC analysis. Matrice d'impacts croises-multiplication appliqúe an classment (crossimpact matrix multiplication applied to classification) is abbreviated as MICMAC. The purpose of MICMAC analysis is to analyze the drive power and dependence power of factors. MICMAC principle is based on multiplication properties of matrix.

Further, ensuring the construct validity, internal validity, external validity and reliability are essential requirements for receiving an enough acceptance for the research findings (Voss et al., 2002). If the operational measures of the particular construct are only measuring the particular construct, the construct validity is satisfied. The two subsets of the construct validity involve convergent validity (multiple items of a construct are corelated) and discriminant validity (individual items of a construct are unique and only measure the particular constructs) (Carmines and Zeller, 1979). To ensure the construct validity, the two paradigms (lean and green) and "sustainable performance" were defined, using multiple items that explain only the construct and are not explain other constructs. Internal validity implies that the study really measures what it is intended. Here, internal validity was ensured through explaining the objectives of this study and simplifying the constructs and items for respondents. External validity implies that the results are valid in similar settings outside the studied objects. This study satisfies the external validity also, because the researcher selected items of each construct as represent both service and manufacturing sectors in Sri Lanka. Meanwhile, the reliability of this study was ensured through selecting respondents from both academia and industry.

\section{Results}

\subsection{Lean, green practices and sustainable performance measures}

As per the opinions of the experts who participated in the focus group, water (1) and material (2) consumption reduction, water pollution (3) and GHG reduction (4) and energy efficiency (5) were determined as the dominant green practices. While, pull production/flow (6), lot size reduction (7), continuous improvement (8), preventive maintenance (9), employee involvement (10) and cycle time reduction (11) were decided as the dominant lean practices. Then as the dominant sustainable performance measures: inventory level (12), profitability (13), quality (14), cost (15), employee satisfaction (16), customer satisfaction (17), lead time (18), resources consumption (19) (material, water, energy) and waste generation (20) were determined.

\subsection{Structured Self-Interaction Matrix}

The Matrix 1 illustrates the interrelationships among the dominant lean, green practices and sustainable performance measures which were determined by the experts who participated
Influence of lean-green practices 
JABES

28,2

130

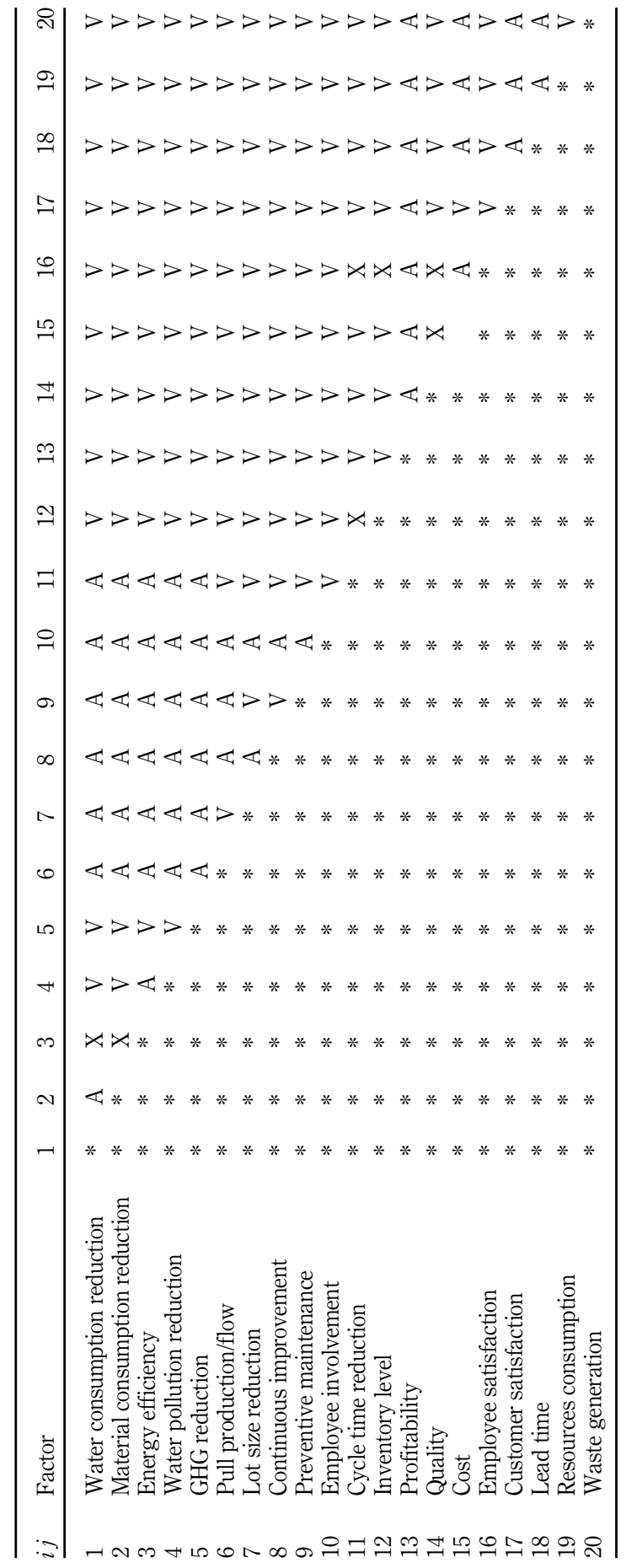

\section{Matrix 1.}

Structured Self-

Interaction Matrix of lean, green practices and sustainable performance measures 
in the focus group. Here four symbols, $V, A, X$ and $O$ are used to denote the direction of the relationship between criterions ( $i$ and j): $\mathrm{V}$ - Criterion i will help to achieve criterion $j, A-$ Criterion $i$ will be achieved by criterion $j, X$-Criterion $i$ and $j$ will help to achieve each other and $O$-Criterion $i$ and $j$ are unrelated. The following would explain the use of the symbols $V$, $A, X$ and $O$ in SSIM (Matrix 1).

Variable 3 (energy efficiency) helps achieve variable 13 (profitability). Thus, the relationship between variable 3 and 13 is denoted by " $V$." Afterward, variable 3 will be achieved by variable 9 (preventive maintenance). Thus, the relationship between variable 3 and 9 is denoted by " $A$ ". Then variable 11 (cycle time reduction) and variable 16 (employee satisfaction) will help to achieve each other. Thus, the relationship between variable 11 and 16 is denoted by " $X$ ".

\subsection{Initial reachability matrix (IRM)}

Matrix 2 demonstrate the IRM which was developed through SSIM. The IRM is derived through transforming the SSIM into a binary matrix substituting $V, A, X, O$ by 1 and 0 as per the case.

The rules for the substitution of 1 s and 0 s is as followings.

If the $(i, j)$ entry in the SSIM is $V$, then the $(i, j)$ entry in the reachability matrix becomes 1 and the $(j$, i) entry becomes 0 .

If the $(i, j)$ entry in the SSIM is $A$, then the $(i, j)$ entry in the reachability matrix becomes 0 and the $(j, i)$ entry becomes 1 .

If the (i, $j)$ entry in the SSIM is $X$, then the $(i, j)$ entry in the reachability matrix becomes 1 and the $(j, i)$ entry also becomes 1 .

If the $(i, j)$ entry in the SSIM is $O$, then the $(i, j)$ entry in the reachability matrix becomes 0 and the $(j, \imath)$ entry also becomes 0 .
Influence of lean-green practices

\begin{tabular}{lllllllllllllllllllll}
\hline$i j$ & 1 & 2 & 3 & 4 & 5 & 6 & 7 & 8 & 9 & 10 & 11 & 12 & 13 & 14 & 15 & 16 & 17 & 18 & 19 & 20 \\
\hline 1 & 1 & 0 & 1 & 1 & 1 & 0 & 0 & 0 & 0 & 0 & 0 & 1 & 1 & 1 & 1 & 1 & 1 & 1 & 1 & 1 \\
2 & 1 & 1 & 1 & 1 & 1 & 0 & 0 & 0 & 0 & 0 & 0 & 1 & 1 & 1 & 1 & 1 & 1 & 1 & 1 & 1 \\
3 & 1 & 1 & 1 & 0 & 1 & 0 & 0 & 0 & 0 & 0 & 0 & 1 & 1 & 1 & 1 & 1 & 1 & 1 & 1 & 1 \\
4 & 0 & 0 & 1 & 1 & 1 & 0 & 0 & 0 & 0 & 0 & 0 & 1 & 1 & 1 & 1 & 1 & 1 & 1 & 1 & 1 \\
5 & 0 & 0 & 0 & 0 & 1 & 0 & 0 & 0 & 0 & 0 & 0 & 1 & 1 & 1 & 1 & 1 & 1 & 1 & 1 & 1 \\
6 & 1 & 1 & 1 & 1 & 1 & 1 & 1 & 0 & 0 & 0 & 1 & 1 & 1 & 1 & 1 & 1 & 1 & 1 & 1 & 1 \\
7 & 1 & 1 & 1 & 1 & 1 & 0 & 1 & 0 & 1 & 0 & 1 & 1 & 1 & 1 & 1 & 1 & 1 & 1 & 1 & 1 \\
8 & 1 & 1 & 1 & 1 & 1 & 1 & 1 & 1 & 1 & 0 & 1 & 1 & 1 & 1 & 1 & 1 & 1 & 1 & 1 & 1 \\
9 & 1 & 1 & 1 & 1 & 1 & 1 & 0 & 0 & 1 & 0 & 1 & 1 & 1 & 1 & 1 & 1 & 1 & 1 & 1 & 1 \\
10 & 1 & 1 & 1 & 1 & 1 & 1 & 1 & 1 & 1 & 1 & 1 & 1 & 1 & 1 & 1 & 1 & 1 & 1 & 1 & 1 \\
11 & 1 & 1 & 1 & 1 & 1 & 0 & 0 & 0 & 0 & 0 & 1 & 1 & 1 & 1 & 1 & 1 & 1 & 1 & 1 & 1 \\
12 & 0 & 0 & 0 & 0 & 0 & 0 & 0 & 0 & 0 & 0 & 1 & 1 & 1 & 1 & 1 & 1 & 1 & 1 & 1 & 1 \\
13 & 0 & 0 & 0 & 0 & 0 & 0 & 0 & 0 & 0 & 0 & 0 & 0 & 1 & 0 & 0 & 0 & 0 & 0 & 0 & 0 \\
14 & 0 & 0 & 0 & 0 & 0 & 0 & 0 & 0 & 0 & 0 & 0 & 0 & 1 & 1 & 1 & 1 & 1 & 1 & 1 & 1 \\
15 & 0 & 0 & 0 & 0 & 0 & 0 & 0 & 0 & 0 & 0 & 0 & 0 & 1 & 1 & 1 & 0 & 1 & 0 & 0 & 0 \\
16 & 0 & 0 & 0 & 0 & 0 & 0 & 0 & 0 & 0 & 0 & 1 & 1 & 1 & 1 & 1 & 1 & 1 & 1 & 1 & 1 \\
17 & 0 & 0 & 0 & 0 & 0 & 0 & 0 & 0 & 0 & 0 & 0 & 0 & 1 & 0 & 0 & 0 & 1 & 0 & 0 & 0 \\
18 & 0 & 0 & 0 & 0 & 1 & 0 & 0 & 0 & 0 & 0 & 0 & 0 & 1 & 0 & 1 & 0 & 1 & 1 & 0 & 0 \\
19 & 0 & 0 & 0 & 0 & 1 & 0 & 0 & 0 & 0 & 0 & 0 & 0 & 1 & 0 & 1 & 0 & 1 & 1 & 1 & 1 \\
20 & 0 & 0 & 0 & 0 & 1 & 0 & 0 & 0 & 0 & 0 & 0 & 0 & 1 & 0 & 1 & 0 & 1 & 1 & 0 & 1
\end{tabular}

Matrix 2. Initial Reachability Matrix (IRM) 
JABES

28,2

The IRM for the SSIM (Matrix 1) is shown in Matrix 2.

\subsection{Final reachability matrix (FRM)}

Matrix 3 exhibit the FRM which was derived through IRM. Integrating the transitivity of the factors in to the IRM, the final reachability matrix is derived. As per the rule of transitivity, if a variable $A$ leads to a variable $B$ and if $B$ leads to another variable $C$, then $A$ leads to $C$. Following this rule, the FRM was developed. Then through the FRM the driving power and dependence of each factor were computed. Driving power means the total number of " 1 " $\mathrm{s}$ in the corresponding rows and dependence is the total number of " 1 "s in the corresponding columns of FRM. Here, the driving power of a particular variable is the total number of variables (including itself) which it may help to achieve other variables. The dependence is the total number of variables which may help in achieving it.

\subsection{Level partition}

Tables 3-10 demonstrate the reachability set, antecedent set, intersection set and level partition of the 20 factors (lean, green practices and sustainable performance measures) which are used to develop the ISM model. As the tables demonstrate, these 20 factors situate in eight levels. Here the reachability and antecedents set of each factor were developed through the FRM. The process of level partition will help to categorize the equally valued elements/factors of prospects.

The reachability set consists of the element itself and other elements, which it may achieve, whereas the antecedent set consists of the element itself and the other elements, which help in achieving it. The elements which are common in reachability sets and antecedent sets are assigned at the intersection set. The reachability sets, the intersection sets and antecedent sets help to pinpoint the level of each element/factor. Within a particular

\begin{tabular}{|c|c|c|c|c|c|c|c|c|c|c|c|c|c|c|c|c|c|c|c|c|c|}
\hline$i, j$ & 1 & 2 & 3 & 4 & 5 & 6 & 7 & 8 & 9 & 10 & 11 & 12 & 13 & 14 & 15 & 16 & 17 & 18 & 19 & 20 & $\begin{array}{c}\text { Driving } \\
\text { power }\end{array}$ \\
\hline 1 & 1 & 1 & 1 & 1 & 1 & 0 & 0 & 0 & 0 & 0 & 1 & 1 & 1 & 1 & 1 & 1 & 1 & 1 & 1 & 1 & 15 \\
\hline 2 & 1 & 1 & 1 & 1 & 1 & 0 & 0 & 0 & 0 & 0 & 1 & 1 & 1 & 1 & 1 & 1 & 1 & 1 & 1 & 1 & 15 \\
\hline 3 & 1 & 1 & 1 & 1 & 1 & 0 & 0 & 0 & 0 & 0 & 1 & 1 & 1 & 1 & 1 & 1 & 1 & 1 & 1 & 1 & 15 \\
\hline 4 & 1 & 1 & 1 & 1 & 1 & 0 & 0 & 0 & 0 & 0 & 1 & 1 & 1 & 1 & 1 & 1 & 1 & 1 & 1 & 1 & 15 \\
\hline 5 & 0 & 0 & 0 & 0 & 1 & 0 & 0 & 0 & 0 & 0 & 1 & 1 & 1 & 1 & 1 & 1 & 1 & 1 & 1 & 1 & 11 \\
\hline 6 & 1 & 1 & 1 & 1 & 1 & 1 & 1 & 0 & 1 & 0 & 1 & 1 & 1 & 1 & 1 & 1 & 1 & 1 & 1 & 1 & 18 \\
\hline 7 & 1 & 1 & 1 & 1 & 1 & 1 & 1 & 0 & 1 & 0 & 1 & 1 & 1 & 1 & 1 & 1 & 1 & 1 & 1 & 1 & 18 \\
\hline 8 & 1 & 1 & 1 & 1 & 1 & 1 & 1 & 1 & 1 & 0 & 1 & 1 & 1 & 1 & 1 & 1 & 1 & 1 & 1 & 1 & 19 \\
\hline 9 & 1 & 1 & 1 & 1 & 1 & 1 & 1 & 0 & 1 & 0 & 1 & 1 & 1 & 1 & 1 & 1 & 1 & 1 & 1 & 1 & 18 \\
\hline 10 & 1 & 1 & 1 & 1 & 1 & 1 & 1 & 1 & 1 & 1 & 1 & 1 & 1 & 1 & 1 & 1 & 1 & 1 & 1 & 1 & 20 \\
\hline 11 & 1 & 1 & 1 & 1 & 1 & 0 & 0 & 0 & 0 & 0 & 1 & 1 & 1 & 1 & 1 & 1 & 1 & 1 & 1 & 1 & 15 \\
\hline 12 & 1 & 1 & 1 & 1 & 1 & 0 & 0 & 0 & 0 & 0 & 1 & 1 & 1 & 1 & 1 & 1 & 1 & 1 & 1 & 1 & 15 \\
\hline 13 & 0 & 0 & 0 & 0 & 0 & 0 & 0 & 0 & 0 & 0 & 0 & 0 & 1 & 0 & 0 & 0 & 0 & 0 & 0 & 0 & 01 \\
\hline 14 & 0 & 0 & 0 & 0 & 1 & 0 & 0 & 0 & 0 & 0 & 1 & 1 & 1 & 1 & 1 & 1 & 1 & 1 & 1 & 1 & 11 \\
\hline 15 & 0 & 0 & 0 & 0 & 0 & 0 & 0 & 0 & 0 & 0 & 0 & 0 & 1 & 1 & 1 & 1 & 1 & 1 & 1 & 1 & 08 \\
\hline 16 & 1 & 1 & 1 & 1 & 1 & 0 & 0 & 0 & 0 & 0 & 1 & 1 & 1 & 1 & 1 & 1 & 1 & 1 & 1 & 1 & 15 \\
\hline 17 & 0 & 0 & 0 & 0 & 0 & 0 & 0 & 0 & 0 & 0 & 0 & 0 & 1 & 0 & 0 & 0 & 1 & 0 & 0 & 0 & 02 \\
\hline 18 & 0 & 0 & 0 & 0 & 1 & 0 & 0 & 0 & 0 & 0 & 0 & 1 & 1 & 1 & 1 & 1 & 1 & 1 & 1 & 1 & 10 \\
\hline 19 & 0 & 0 & 0 & 0 & 1 & 0 & 0 & 0 & 0 & 0 & 0 & 1 & 1 & 1 & 1 & 1 & 1 & 1 & 1 & 1 & 10 \\
\hline 20 & 0 & 0 & 0 & 0 & 1 & 0 & 0 & 0 & 0 & 0 & 0 & 1 & 1 & 1 & 1 & 1 & 1 & 1 & 1 & 1 & 10 \\
\hline $\begin{array}{l}\text { Dependence } \\
\text { Power }\end{array}$ & 12 & 12 & 12 & 12 & 17 & 05 & 05 & 02 & 05 & 01 & 14 & 17 & 20 & 18 & 18 & 18 & 19 & 18 & 18 & 18 & $\sum=261$ \\
\hline
\end{tabular}




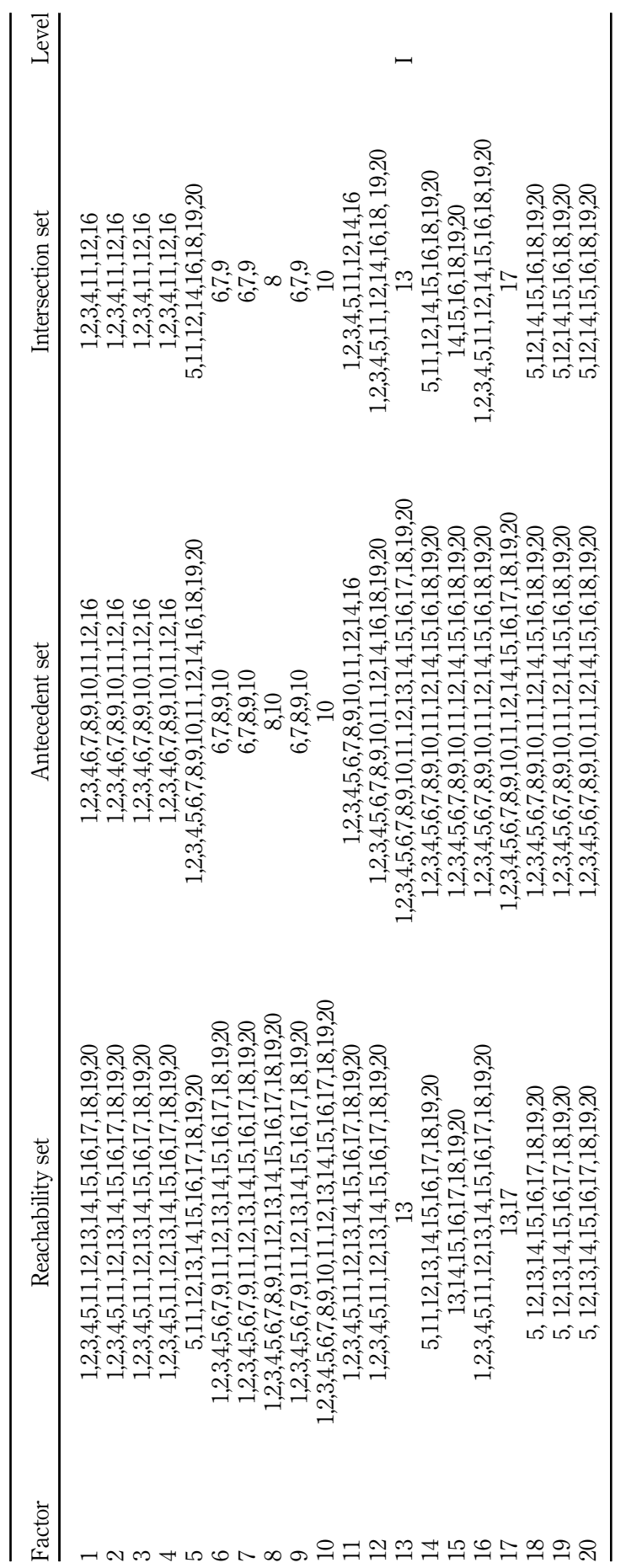

Influence of lean-green practices

133

Table 3. Iteration one 
JABES

28,2

134

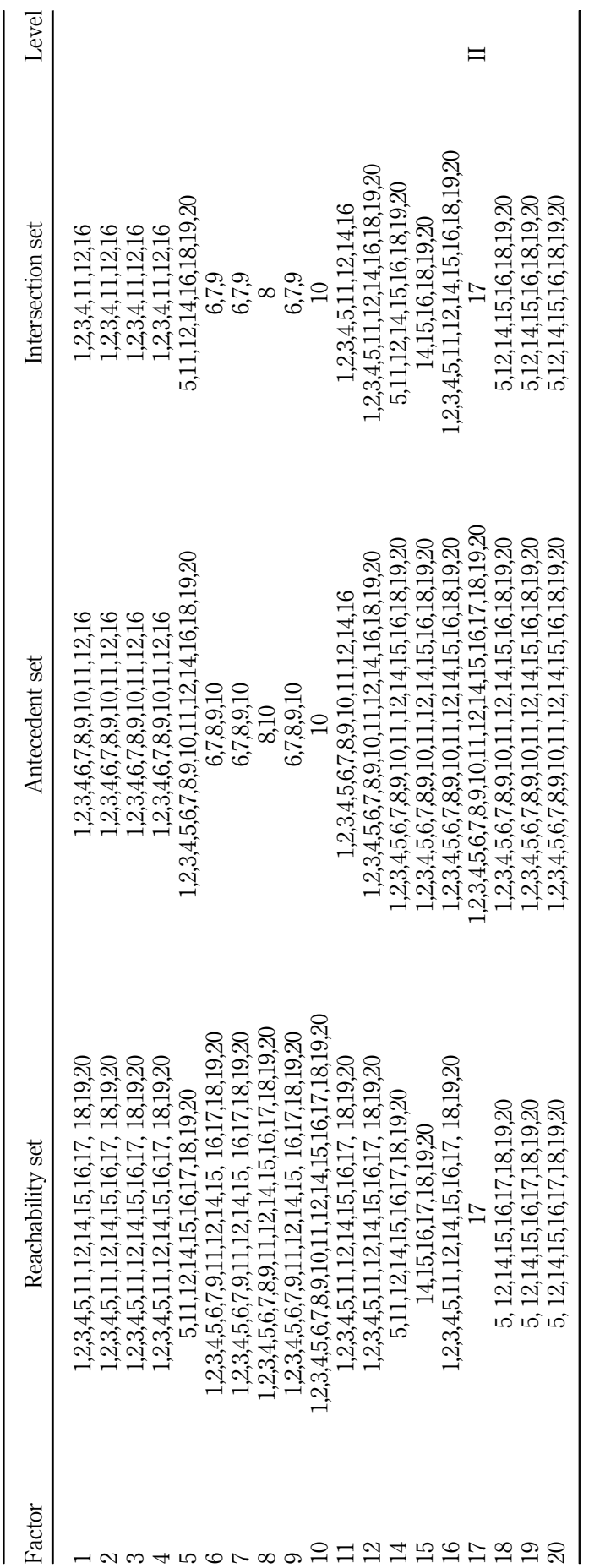

Table 4.

Iteration two 


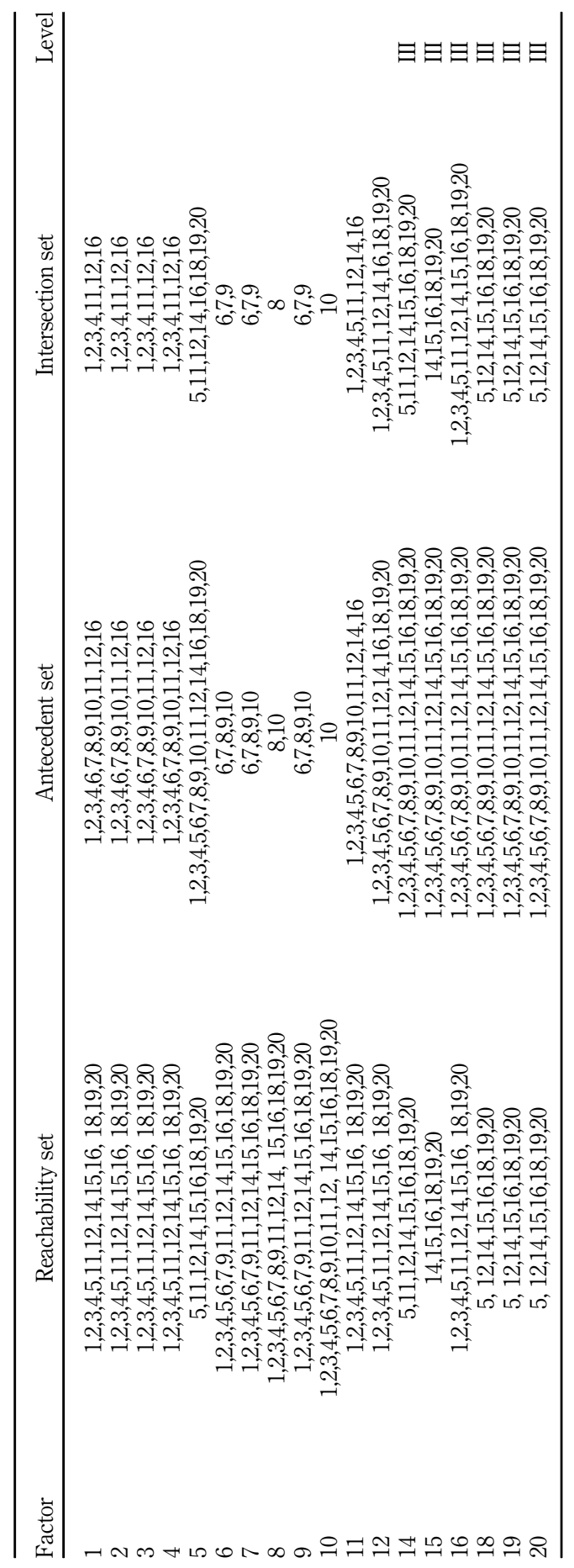

Influence of lean-green practices

135

Table 5. Iteration three 


\section{JABES \\ 28,2}

\begin{tabular}{lcccc}
\hline Factor & Reachability set & Antecedent set & Intersection set & Level \\
\hline 1 & $1,2,3,4,5,11,12$ & $1,2,3,4,6,7,8,9,10,11,12$ & $1,2,3,4,11,12$ & \\
2 & $1,2,3,4,5,11,12$ & $1,2,3,4,6,7,8,9,10,11,12$ & $1,2,3,4,11,12$ & \\
3 & $1,2,3,4,5,11,12$ & $1,2,3,4,6,7,7,8,9,10,11,12$ & $1,2,3,4,1,12$ & \\
4 & $1,2,3,4,5,11,12$ & $1,2,3,4,6,7,8,9,10,11,12$ & $1,2,3,4,11,12$ & \\
5 & $5,11,12$ & $1,2,3,4,5,6,7,8,9,10,11,12$ & $5,11,12$ & IV \\
6 & $1,2,3,4,5,6,7,9,11,12$ & $6,7,8,9,10$ & $6,7,9$ & \\
7 & $1,2,3,4,5,6,7,9,11,12$ & $6,7,8,9,10$ & $6,7,9$ & \\
8 & $1,2,3,4,5,6,7,8,9,11,12$ & 8,10 & 8 & \\
9 & $1,2,3,4,5,6,7,9,11,12$ & $6,7,8,9,10$ & $6,7,9$ & \\
10 & $1,2,3,4,5,6,7,8,9,10,11,12$ & 10 & 10 & \\
11 & $1,2,3,4,5,11,12$ & $1,2,3,4,5,6,7,8,9,10,11,12$ & $1,2,3,4,5,11,12$ & IV \\
12 & $1,2,3,4,5,11,12$ & $1,2,3,4,5,6,7,8,9,12,11,12$ & $1,2,3,4,5,11,12$ & IV \\
\hline
\end{tabular}

Table 6.

Iteration four

\begin{tabular}{lcccc}
\hline Factor & Reachability set & Antecedent set & Intersection set & Level \\
\hline 1 & $1,2,3,4$ & $1,2,3,4,6,7,8,9,10$ & $1,2,3,4$ & $V$ \\
2 & $1,2,3,4$ & $1,2,3,4,6,7,8,9,10$ & $1,2,3,4$ & $V$ \\
3 & $1,2,3,4$ & $1,2,3,4,6,7,8,9,10$ & $1,2,3,4$ & $V$ \\
4 & $1,2,3,4$ & $1,2,3,4,6,7,8,9,10$ & $1,2,3,4$ & $V$ \\
6 & $1,2,3,4,6,7,9$ & $6,7,8,9,10$ & $6,7,9$ & \\
7 & $1,2,3,4,6,7,9$ & $6,7,8,9,10$ & $6,7,9$ & \\
8 & $1,2,3,4,6,7,8,9$ & 8,9 & 8 & \\
9 & $1,2,3,4,6,7,9$ & $6,7,8,9,10$ & $6,7,9$ & \\
10 & $1,2,3,4,6,7,8,9,10$ & 10 & 10 & \\
& & & &
\end{tabular}

Table 7.

Iteration five

\begin{tabular}{lrccc}
\hline Factor & Reachability set & Antecedent set & Intersection set & Level \\
\hline 6 & $6,7,9$ & $6,7,8,9,9$ & $6,7,9$ & VI \\
7 & $6,7,9$ & $6,7,8,9,10$ & 8,9 & VI \\
8 & $6,7,8,9$ & 8,10 & 8 & \\
9 & $6,7,9$ & $6,7,8,9,10$ & $6,7,9$ & VI \\
10 & $6,7,8,9,10$ & 10 & 10 & \\
\hline
\end{tabular}

Table 8.

Iteration six

\begin{tabular}{lcccc}
\hline Factor & Reachability set & Antecedent set & Intersection set & Level \\
\hline 8 & 8 & 8,10 & 8 & VII \\
10 & 8,10 & 10 & 10 & \\
\hline
\end{tabular}

Table 9.

Iteration seven

\begin{tabular}{lcccc}
\hline Factor & Reachability set & Antecedent set & Intersection set & Level \\
\hline 10 & 10 & 10 & 10 & VIII \\
\hline
\end{tabular}

Table 10.

Iteration eight 
iteration, when all the elements of the intersection set and reachability sets of a particular factor are rare same, then that factor is assigned a level (i.e. level 1). Then in the next iteration (i.e. Level 2), the factors which was assigned a level is removed. This process is repeated till the levels of each factor are found. These levels recognized by this procedure are exploited for the formation of diagraph.

As iteration tables exhibit, profitability (13) was the level one variable and customer satisfaction (17) was the level two variable. Meanwhile, quality (14), cost (15), employee satisfaction (16), lead time (18), resources consumption (19) and waste generation (20) situated in the level three. Then GHG reduction (5), cycle time reduction (11) and inventory level (12) received the fourth level and water consumption reduction (1), material consumption reduction (2), energy efficiency (3) and water pollution reduction (4) received the fifth level. Further pull production, lot size reduction and preventive maintenance represented the level six and continuous improvement represented the level seven. Ultimately employee involvement received the level eight.

\subsection{ISM based model of lean, green practices and sustainable performance measures}

Figure 2 demonstrates the structural model which was generated through the final reachability matrix. Here, dependent variables situate in the top of the ISM model, while independent variables exist in the bottom of it.

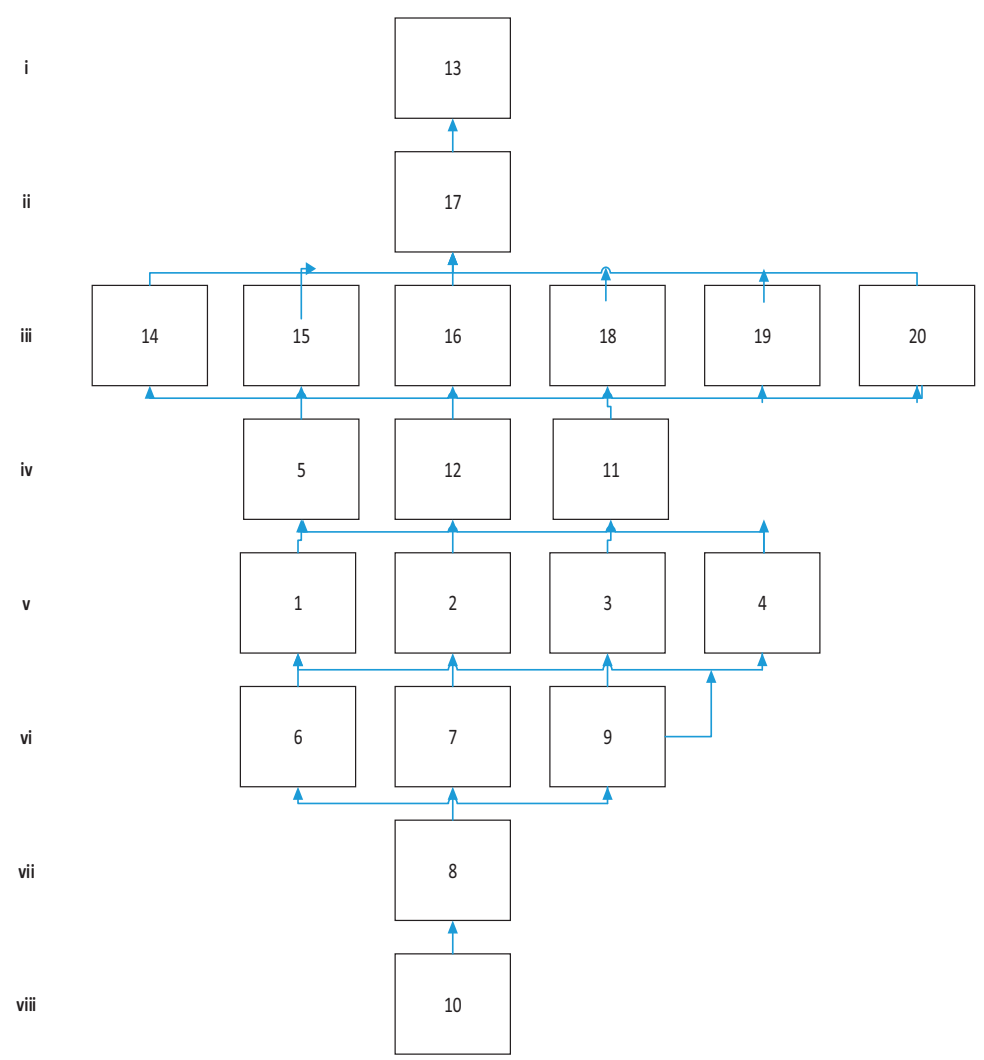

Figure 2.

ISM-based model of lean, green practices and sustainable performance measures
Influence of lean-green practices 
JABES

28,2

138

\subsection{MICMAC analysis}

MICMAC principle is based on multiplication properties of matrix. This analysis is done to identify the key factors that drive the system. Here, based on the driving power and dependence, which is found in the final reachability metrics, a graph is plotted as shown in the Figure 3, classifying the factors into four clusters as (1) Autonomous, (2) Dependent, (3) Linkage and (4) Independent factors. Autonomous group has low driving power and low dependence. They can be eliminated from the system. Dependent group has low driving power and high dependence. Linkage group has high driving power and high dependence. They are the most important elements. Any action on this will affect the entire system. Then, independent group has high driving power and low dependence.

The following would explain the way of plotting each variable under these four categories.

e.g. Variable 15 (cost) has been plotted in the dependence category. In this variable the dependence power is 18 and independence/driving power is eight (Matrix 3). Thus, the coordinates of the variable are " 18,8 ". Further borders of the four sections are derived through dividing the total number of variables $(n)$ by two $(n / 2)$. Here the number of variables is 20 , thus the border is built in coordinate "10,10" (see Figure 3).

\section{Conclusion}

The primary objective of the study was to develop a structural model of the green, lean practices and sustainable performance measures with reference to business organizations in Sri Lanka. For achieving this research objective, at first the researcher wanted to select the dominant green, lean practices and sustainable performance measures used by the Sri Lankan business organizations.

Water consumption reduction, material consumption reduction, energy efficiency, water pollution reduction and GHG reduction were identified as the dominant green practices, while

Figure 3.

MICMAC analysis

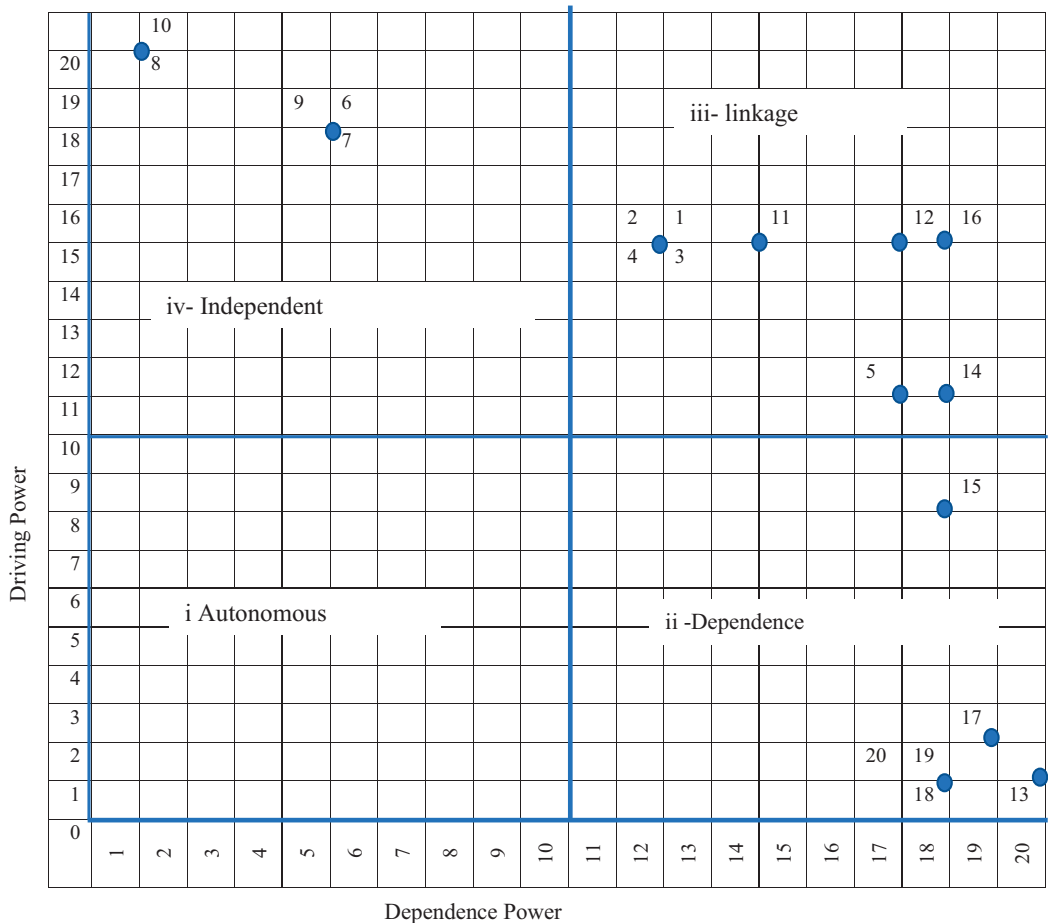


pull production, lot size reduction, continuous improvement, preventive maintenance, employee involvement and cycle time reduction were the dominant lean practices. Then inventory level, profitability, quality, cost, employee satisfaction, customer satisfaction, lead time, resources consumption (material, water, energy) and waste generation were determined as the dominant sustainable performance measures.

Subsequently the researcher determined the interrelationships among these dominant factors base on the opinions of the experts. Finally, the researcher categorized the lean, green practices and sustainable performance measures in to four categories of autonomous, dependent, linkage and independent variables through the MICMAC analysis. Here profitability, cost, customer satisfaction, lead time, resources consumption (material, water, energy) and waste generation situates in the dependent category. Meanwhile independent category represents the pull production/flow, lot size reduction, continuous improvement, preventive maintenance and employee involvement. Then water consumption reduction, material consumption reduction, energy efficiency, water pollution reduction, GHG reduction, cycle time reduction, inventory level, quality and employee satisfaction are in the linkage category. Based on this categorization it can be concluded that sustainable performance measures: profitability, cost, customer satisfaction, lead time, resources consumption (material, water, energy) and waste generation depend on the lean practices: pull production/flow, lot size reduction, continuous improvement, preventive maintenance and employee involvement.

Further the resulting ISM model (Figure 2) consisted of eight levels. As the ISM methodology emphasizes, factors that represent the bottom of the model are rich in driving power and top of the model consist of factors which are rich in dependence power. As Figure 1 demonstrates, lean practices situate in the bottom of the model, while green practices stand in the middle section of the model and sustainable performance measures exist in the top of the model. So, through this ISM model it can be clearly concluded that lean practices influence green practices and green practices affect sustainable performance measures. Further it can be concluded that green practices play as the moderating factors and lean practices as the independent factors of the ISM model.

\subsection{Implications}

The organizations who desire to improve the sustainable performance are suggested to initiate with lean, and subsequently move in to green. Also, it is suggested to handle both lean and green practices through one functional unit. Here the initial efforts should concern the lean improvement and subsequent effort should focus the green improvements. Then organizations can reduce their overlapping efforts and cost of separately implementation of lean and green. Further this model will help to practitioners to identify the link between lean, green and performance measure, in lean and green implementation through the same functional unit.

\subsection{Future research directions}

The research contributed to the existing knowledge through developing an ISM-based structural model that explain the interactions among lean paradigm, green paradigm and sustainable performance measures. The research used expert opinions only, in building this structural model and it was not tested empirically. Thus, the research opens an opportunity for future research studies to empirically test this model, through a quantitative study using the analytical methods like structural equation modeling.

\section{References}

Azevedo, S.G., Carvalho, H. and Cruz-Machado, V. (2016), "LARG index: a benchmarking tool for improving the leanness, agility, resilience and greenness of the automotive supply chain", Benchmark, Vol. 23 No. 6, pp. 1472-1499. 
JABES

28,2

140

Banerjee, S. (2002), "Corporate environmentalism: the construct and its measurement", Journal of Business Research, Vol. 55 No. 3, pp. 177-191.

Bergmiller, G.G. and McCright, P.R. (2009), "Parallel models for Lean and green operations", paper presented at the Industrial Engineering Research Conference, 2009, Miami, FL, p. 30, May-3 June, available at: https://pdfs.semanticscholar.org/0a67/c7f0f6d60ba0506e037aaf17cfe8b3a89e7d.pdf (accessed 10 February 2019).

Bhasin, S. (2015), Lean Management Beyond Manufacturing, A Holistic Approach, Springer International Publishing, Switzerland.

Brundtland, G. (1987), Report of the World Commission on Environment and Development: Our Common Future, United Nations General Assembly document A/42/427, United Nations.

Cabral, I., Grilo, A. and Cruz-Machado, V. (2012), “A decision-making model for Lean, Agile, Resilient and Green supply chain management", International Journal of Production Research, Vol. 50 No. 17 , pp. $4830-4845$.

Carmines, E.G. and Zeller, R.A. (1979), Reliability and Validity Assessment, Sage University Paper Series on Quantitative Applications in the Social Sciences, Sage Publications, Newbury Park, pp. 7-17.

Creswell, J.W. (2014), Research Design: Qualitative, Quantitative, and Mixed Methods Approaches, 4th ed., SAGE Publications, Thousand Oaks, California.

David, F.R. (2011), Strategic Management: Concepts and Cases, Global ed., 13th ed., Pearson Education, Upper Saddle River.

Dües, C., Tan, K. and Lim, M. (2013), "Green as the new Lean: how to use Lean practices as a catalyst to greening your supply chain”, Journal of Cleaner Production, Vol. 40, pp. 93-100.

Elkington, J. (1998), Cannibals with Forks: The Triple Bottom Line of 21st Century Business, New Society Publishers, Gabriola Island, Stony Creek.

Enquist, B., Edvardsson, B. and Sebhatu, S.P. (2007), "Values-based service quality for sustainable business, managing service quality", Journal of Service Theory and Practice, Vol. 17 No. 4, pp. 385-403.

Farias, L.M.S., Santos, L.S., Gohr, C.F. and Rocha, L.O. (2019), “An ANP-based approach for lean and green performance assessment”, Resources, Conservation and Recycling, Vol. 143, pp. 77-89.

Galeazzo, A., Furlan, A. and Vinelli, A. (2014), "Lean and green in action: interdependencies and performance of pollution prevention projects", Journal of Cleaner Production, Vol. 85, pp. 191-200.

Galeazzo, A., Furlan, A. and Vinelli, A. (2014), "Understanding environmental-operations integration: the case of pollution prevention projects", International Journal of Production Economics, Vol. 153 No. c, pp. 149-160.

Garza-Reyes, J.A. (2015), "Lean and green: a systematic review of the state-of-the-art literature", Journal of Cleaner Production, Vol. 102, pp. 18-29.

Global Reporting Initiative (2017), available at: https:/www.globalreporting.org/standards/gristandards-download-center (accessed 30 May 2019).

Govindan, K., Azevedo, S.G., Carvalho, H. and Cruz-Machado, V. (2015), "Lean, green and resilient practices influence on supply chain performance: interpretive structural modeling approach", International Journal of Environmental Science and Technology, Vol. 12 No. 1, pp. 5-34.

Hallam, C. and Contreras, C. (2016), "Integrating lean and green management”, Management Decision, Vol. 54 No. 9, pp. 2157-2187.

Hartini, S. and Ciptomulyono, U. (2015), "The relationship between lean and sustainable manufacturing on performance: literature review", Procedia Manufacturing, Vol. 4, pp. 38-45.

Henao, R., Sarache, W. and Gómez, I. (2019), "Lean manufacturing and sustainable performance: trends and future challenges", Journal of Cleaner Production, Vol. 208, pp. 99-116.

Jurado, M., José, P. and Fuentes, J.M. (2014), "Lean management, supply chain management and sustainability: a literature review", Journal of Cleaner Production, Vol. 85, pp. 134-150.

Kaplan, R.S. and Norton, D.P. (1996), The Balanced Scorecard: Translating Strategy into Action, First ed., Harvard Business School Press, Boston. 
Khalili, A., Ismail, M.Y., Karim, A.N.M. and Daud, M.R.C. (2016), "relationships of lean, green manufacturing and sustainable performance: assessing the applicability of the proposed model", paper presented at, International Conference on Industrial Engineering and Operations Management, 2016, Kuala Lumpur, Malaysia, 8-10 March, available at: http://ieomsociety.org/ ieom_2016/pdfs/179.pdf (accessed 12 May 2019).

Kovilage, M.P. (2018), "Influence of lean and green paradigms on supply chain performance: an interpretive structural modelling approach", Paper presented at, International Conference on Multidisciplinary Researches, 2018, Maldives National University, Maldives, August, pp. 12-13.

Krajnc, D. and Glavic, P. (2005), “A model for integrated assessment of sustainable development", Resources, Conservation and Recycling, Vol. 43, pp. 189-208.

Lee, K.H. and Saen, R.F. (2011), "Measuring corporate sustainability management: a data envelopment analysis approach", International Journal of Production Economics, Vol. 140 No. 1, pp. 219-226.

Loknath, B. and Azeem, A. (2017), “Green management -concept and strategies”, Paper Presented at, National Conference on Marketing and Sustainable Development, 2017, Rajampet, Andhra Pradesh, 13-14 Octomber, available at: https:/www.researchgate.net/publication/330089504_ Green_Management-Concept_and_Strategies (accessed 12 May 2019).

Möller, A. and Schaltegger, S. (2005), "The sustainability balanced scorecard as a framework for ecoefficiency analysis", Journal of Industrial Ecology, Vol. 9 No. 4, pp. 73-83.

Morin, E.M. (1995), "Organizational effectiveness and the meaning of work", in Pauchant, T.C. et al. (Ed.), Search of Meaning. Managing for the Health of Our Organizatons, Our Communities, and the Natural World, Jossey-Bass, San Francisco, pp. 29-64.

Peng, Y. and Lin, S. (2008), "Local responsiveness pressure, subsidiary resources, green management adoption, and subsidiaries performance: evidence from Taiwanese manufacturers", Journal of Business Ethics, Vol. 79 Nos 1-2, pp. 199-212.

Sebhatu, S.P. (2008), "Sustainability performance measurement for sustainable organizations: beyond compliance and reporting", 11th Quality Management and Organizational Development- QMOD Conference, 2008, Attaining Sustainability from Organizational Excellence to Sustainable Excellence, Helsingborg, Sweden, 20-22 August, available at: http://www.ep.liu.se/ecp/033/005/ ecp0803305.pdf (accessed 12 May 2019).

Thanki, S.J. and Thakkar, J.J. (2016), "Value-value load diagram: a graphical tool for lean-green performance assessment”, Production Planning and Control, Vol. 27, pp. 1280-1297.

Verrier, B., Rose, B., Caillaud, E. and Remita, H. (2014), "Combining organizational performance with sustainable development issues: the lean and green project benchmarking Repository", Journal of Cleaner Production, Vol. 85, pp. 83-93.

Voss, C., Tsikriktsis, N. and Frohlich, M. (2002), "Case research in operations management", International Journal of Operations and Production Management, Vol. 22 No. 2, pp. 95-219.

Warfield, J.N. (1974), "Towards Interpretation of complex structural models. IEEE transactions", System, Man and Cybernetics- SMC, Vol. 4 No. 5, pp. 405-417.

Wiese, A., Luke, R., Heyns, G.J. and Pisa, N.M. (2015), "The integration of lean, green and best practice business principles", Journal of Transport and Supply Chain Management, Vol. 9 No. 1, pp. 192-202.

Womack, J.P. and Jones, D.T. (1994), "From lean production to the lean enterprise", Harvard Business Review, March-April, pp. 93-103.

Womack, J.P. and Jones, D.T. (1996), Lean Thinking: Banish Waste and Create Wealth in Your Corporation, Simon and Schuster, New York.

Wu, L., Subramanian, N., Abdulrahman, M.D., Liu, C., Lai, K. and Pawar, K.S. (2015), “The impact of integrated practices of lean, green, and social management systems on firm sustainability performance-evidence from Chinese fashion auto-parts suppliers", Sustainability, Vol. 7 No. 4, pp. 3838-3858. 
JABES

28,2

142

\section{Further reading}

Figge, F., Hahn, T., Schaltegger, S. and Wagner, M. (2002), "The sustainability balanced scorecard theory and application of a tool for value-based sustainability management", Paper presented at, The Greening of Industry Network Conference, 2002, Gothenburg, 23-26 June, available at: https:// www.academia.edu/553663/The_Sustainability_Balanced_Scorecard_Theory_and_Application_ of_a_Tool_for_Value-Based_Sustainability_Management (accessed 11 June 2019).

Fleisher, C.S. (2003), "Managing the grassroots and assessing its performance", Journal of Public Affairs, Vol. 3 No. 4, pp. 371-382.

\section{Corresponding author}

Manori Pathmalatha Kovilage can be contacted at: manori@mgt.sab.ac.lk

For instructions on how to order reprints of this article, please visit our website:

www.emeraldgrouppublishing.com/licensing/reprints.htm

Or contact us for further details: permissions@emeraldinsight.com 